\title{
ILMU KANURAGAN AT ROHMATUL UMMAH ASSALAFY PESANTREN OF JEKULO KUDUS
}

\author{
Mukhamad Rikza \\ The State Institute of Islamic Studies of Walisongo, Semarang
}

\begin{abstract}
Pesantren are one source of knowledge, especially in Indonesia. Almost in every district in Java region in particular there is a boarding school, from which inhabited tens to thousands of students. The style of education offered also varied, from the shape of the Salaf to modern. There is also a yellow book offers study programs in an effort to preserve the concept of shariah brought by salaf scholars who in fact are the inheritors of the prophets. In addition to studying the book of yellow, there is also a boarding school who study science kanuragan (supernatural power) or martial arts. All have their respective advantages which aims to preserve Islamic values berasas on the Qur'an and hadith. Yellow Book and science kanuragan into a Pesantren tradition that can not be released. Science kanuragan very beneficial, especially before the independence of Indonesia. Therefore, the students participate in running the missions and fight against criminals and invaders. Science kanuragan, when it plays a lunch the students to fight for independence and the provision of da'wah. Teaching science kanuragan felt to be more urgent for the "protection" in the face of the enemy. At that science to be excellent kanuragan interesting to study.
\end{abstract}

Keywords: ilmu kanuragan, pesantren, Jekula kudus

\section{INTRODUCTION}

There are four educational institutions which play a role in the internal structure of Islamic education in Indonesia, namely: Islamic boarding schools, madrasah education, Islamic-based public education and Islamic religious studies conducted in public schools (Mochtar Buchori, 1994: 243-244). He called the Pesantren as Islamic education that is organized traditionally, based on the teaching of the Qur'an and the Hadith and designing all of its educational activities to teach to Muslim students of as a way of life.

The Pesantren in Indonesia has become the center of teaching and Da'wah (Islamic proselytization). It has played an important role because it is the oldest system of learning and education in Indonesia (MA. Sahal Mahfudh, 1990: 1). Socially, the Pesantren has played an important role in the spread of Islam in Indonesia. It has become a formal socialization media where the beliefs, norms, and values of Islam are transmitted and cultivated through teaching. 
It is a means for the development of Islamic teachings and maintenance of orthodoxy. The pesantren is only one of the examples of the tradition of scholarship and oldest traditional thoughts in Indonesia at present (Ismail SM et al, 2000: 171).

Life in the pesantren is a miniature of life in society. All aspects of life interact in the midst of life at the boarding school. This is where the santri (pesantren students) being intensively educated by the environment, and in turn they are capable of living in a community and even integrate themselves in the development of the dynamics of the community independently.

The guardians and scholars teach the substance of Islamic teachings that are close to the needs of the community. The model of spreading the Islamic religion is done in various ways. Its muballigh, both the guardians and the ulemas or kiai are required to be more competent compared to other members of the community. The competence of knoledge itself becomes the main requirement, but in addition to the knowledge, they need to have extra skills, such as the pleasant-sounding voice, special knowledge in the treatment of diseases, and expertise in conquering the spirits, criminals or repelling evil spirits. Otherwise, their presence is considered incompetent of protecting those whom they come to preach on.

With the extra skills they have, the can easily combine the Islamic Da'wah with the teaching of tawhid (oneness of God) and suwu' (the Islamic mantra). That way many people can learn spells to survive the catastrophe, and consequently more people will be interested in studying religion. Through rescue and protection, people will finally be interested in embracing Islam. Such activity is synonymous with the tradition of ilmu kanuragan (literally: Kanuragan science).

Ilmu kanuragan is often identified with supernatural power and skills in spiritual treatment. People with this power are beyond the limits of human nature and considered to have a superior kanuragan science. In some boarding schools --although not officially-- the practice to achieve certain supernatural power is taught to the students. However, most people consider the practice of kanuragan does not come from the teachings of Islam but from kejawen (Javanese culture). In fact, the pesantren should become a pioneer to provide enlightenment that such supernatural power should be derived from the Qur'an, the Hadith or the Yellow Books (Islamic manuscripts).

One of the Pesantren that teaches a blend of kanuragan science and the Yellow Books is the Rohmatul Ummah Assalafy Pesantren of Jekulo Kudus. The boarding school was officially established on January 10, 1989. This pesantren 
has since been known as the kanuragan boarding school characterized by its long haired students. The principal of the boarding school, $\mathrm{KH}$ Mahmudi is also also called Kiai Gondrong (Long-haired Kiai) as he has long hair.

In light of the above information, a study on Rohmatul Ummah Pesantren as a model of Kanuragan -based boarding school is very significant to be conducted. The results of this research are expected to be a reference for the development of pesantren in order to keep the tradition of the Yellow Books and preserve the tradition of kanuragan science by practicing the values of the Qur'an and Hadith. Today, the kanuragan science has started to lose devotees, so it needs to be preserved for future enthusiasts.

The focus of this study is: what kanuragan science is taught in this the Rahmatul Ummah pesantern? What is the students' motivation for learning the kanuragan science at the Rahmatul Ummah pesantren? What is the purpose of learning the kanuragan science at the Rahmatul Ummah pesantren? How is the kanuragan science taught at the Rahmatul Ummah pesantern? This study employs the continuity description that has the characteristics of qualitative research. The continuity description is doing research in a descriptive manner conducted continuously over an object of research (Moh. Nazir, Metode Penelitian, 2005: 56). So, in researching the kanuragan science at the Rahmatul Ummah Pesantren, the researcher will examine and describe systematically the overview, facts and nature of the existing phenomena.

\section{A BROADER DEFINITION OF THE KANURAGAN SCIENCE}

The Kanuragan Science has always been identified with a science that provides supernatural power in a person. The kanuragan science in the Javanese term, is also known as ngelmu kanuragan. The word ngelmu, derived from the Arabic word "ilmu", means knowledge and skills. However, in the Javanese language, the word "ngelmu" has a much broader meaning that includes sayings, oath, or spell. The Javanese people also define ngelmu as practical skills to perform special deeds (Capt. R.P. Suyono, 2009: 77).

There are two types of Ngelmu, namely the first ngelmu and second ngelmu. The first ngelmu, consisting of a number variants, each having its own spell, is characterized by the presence of a script, calculation, or certain things that give a person certain power. However, at present, only little is known, where most has been mixed in the transition of knowledge from a father to a son or from a teacher to students.

While the meaning of kanuragan is very diverse. Obviously, kanuragan is a term in the Javanese language. In the Javanese language dictionary (Bausastra 
Jawa), it is explained that kanuragan means kedotan (Widada et al, 2008: 338). Kedotan means power, so kanuragan can be defined as a science that studies power. Budiono Heru Satoto gave another definition. The word kanuragan is derived from the old Javanese word "anuraga" which means great. The greatness is not resistance that comes from outside, but the subtle unseen energy that appears and expands in the body of a person derived from his/her own power, thanks to the training in accordance with the principles and methods of mesubudi and mesuraga that are taught by a teacher. Parsudi Suparlan (2001) explained that:

"Elmu Kanuragan (knowledge for strengthening the body; kanuragan is derived from the word raga or body) ... Elmu kanuragan is also designed to prepare the young to attain more power from the universe and knowledge of elmu ... They said that the best way to learn things is through a teacher, but especially for the elmu kanuragan, any slight error may endanger one's life. It's out there but not many young Javanese today know elmu kanuragan ".

However, some interpret the owrd kanuragan as physical exercise through the art of persilatan (martial arts) (Budiono Heru Satoto, 2009: 2003). The art of persilatan is a means of physical exercise in the form of physical techniques (kicks, hand strikes, avoiding attack or defending/fortifying oneself, etc) in martial arts. As practiced in jaya kawijayan, in the kanuragan, the moves are used for self defense from attack (digdaya). Pencak silat is the skill on the outside, while the power inside is called kadibyan jati (pure power or power that exceeds the ordinary power).

So kanuragan is the science that serves to defend oneself in a supernatural way. This knowledge includes the ability to survive against attack and the ability to attack with an extraordinary power, for example using the angelic hizib science, inner power hizib, ultimate shahada, and so on (Aulia, 2009: 67). To embody the teachings of the Islamic-based kanuragan, the pesantren needs to perform it with a mix of a study of the Yellow Books. It is from the teachings of the Yellow Books that the students can get the Islamic values, especially in terms of the spiritual treatment and martial arts through strengthening faith psychologically. Therefore the pesantren remains at its position as a keeper of the Islamic traditions which have an important role, especially in the development of religious values in society. In addition, the pesantren has a duty in serving as a "traditional medicine" because the role of traditional medicine practitioners in rural communities is still important.

In line with the development, the role of traditional healers has started to be developed with a blend of classical sciences (Salafiah) based on the Yellow 
Books and modern science. The kanuragan science is also closely related to the traditional medicine and has widely been known. Syekh al-Zarnuji explained the nature of science; the science of things, the science of wasilah, the science of ahwal al-Qulub, the science of personality and science ketabiban (traditional medicine practitioner). The science of ketabiban, as al-Zarnuji described, is the science of health, drugs and diseases. In addition to these, there are four science disciplines that need to be learned, namely: philosophy, the science of manthiq, jidad and nujum (Busyairi Madjidi, 1997: 111-112).

\section{KANURAGAN SCIENCE AT THE ROHMATUL UMMAH ASSALAFY PESANTREN}

The Rohmatul Ummah Assalafy Pesantren founded by K.H. Mahmudi Amam on January 10, 1989 is located on the Jalur Pantura on the $9^{\text {th }} \mathrm{km}$ between Kudus -Pati. After a few years of running, the second pesantren, Rohmatul Ummah Assalafy II was founded in 1994 and led by Kyai Ahmad Syadzalie Ridwan. Later, in 1997 Kyai Abdul Madjid founded the third pesantren bearing the same name, Rohmatul Assalafy III. In its development, the three boarding schools have their own autonomous entities managed by each principal, but certainly in the management of the educational program, they use the curriculum agreed upon together.

The name "Rohmatul Ummah Assalafy " was selected as by Kyai Mahmudi with a hope that the cadres or alumni will provide bring grace and protection to all walks of life. This is in accordance with the verse of the Quran: "Wama arsalnaka Illa rohmatan lilalamin". What Kyai Mahmudi meant is that the knowledge acquired at the Rohmatul Ummah, should really be practiced and spread so that it can be a good role model for society.

$\mathrm{KH}$ Mahmudi explained that "the long hair tradition" is among the characteristics of the Rohmatul Ummah Pesantren. However, the characteristic is not synonymous with negative behavior. The bottom line is the desire to face of life with determination and resilience, having a view into the future symbolized by hair growing lengthwise. The students who study at the Rohmatul Ummah pesantren always have lessons combined with moral education in one package. Therefore, many students --in addition to active learning-- also observe fasting every Monday and Thursday, as well as the every-other-day fasting of the Prophet David, and observe annual fasting (dalail). The tradition is called tirakat.

The main tenets of the pesantren are teaching the students to be flexible rather than to be aggressive and radical. The students are also expected to continue inter-discipline education as a legacy of the salafulemas. With the combination 
of the education system, the pesantren's obsession is to retain the salafi values. These values do not oppose changes or modernization, but represent a symbol of honesty and a filter in stemming the tide of globalization and the culture that might harm the personality of the nation.

The secret to becoming successful students at the Rahmatul Ummah pesantren is embodied in symbols of being AKIK (aktif, kreatif, imajinatif, dan komunikatif) (active, creative, imaginative, and communicative). In addition, there is still one more slogan: DUIT (doa, usaha, iman, dan takwa) meaning prayer, effort, faith and piety. The two slogans are always instilled to students that efforts are essential for their development to face life in the community. Therefore, in order to be a religion expert who has the competence in the field of the kanuragan science and the Yellow Books one needs to be educated at the Rahmatul Ummah pesantren independently.

\section{Types of Kanuragan Science}

Kyai Mahmudi always give advice to the students:

1. Bocah-bocah santri wajib ngaji (students must recite the Qur'an )

2. Bocah-bocah santri wajib hormat, tunduk lan ngladeni marang guru (students must respect the teachers)

3. Bocah-bocah santri podo meluho jamaah lan mujahadah bareng guru

Besides, another advice is: Kowe yen kepingin results science benefits blessings dunyo akirat lakonono lan antengono vou mahu pensioner studious utowo sinahu lan ngibadah! The researcher divided the three kinds of kanuragan that are learnt by the students at Rohmatul Ummah pesantren.

\begin{tabular}{|l|l|l|}
\hline Mujahadah & Riyadlah & Fasting \\
\hline Yellow Book recital & Nasi jagung & David \\
\hline Berjanjen & Telo & Dalail khairat \\
\hline Tahlil & Nggondrong & Dalail al-Qur'an \\
\hline Istighatsah & Ngrowot & Ninggal nyowo \\
\hline Alfiyahan & Hizb & Monday-Thursday \\
\hline Manakiban & Malakut & Pathi geni \\
\hline Bai'atan & Karamahan/Setruman & Rejeb \\
\hline & Ngebleng & Syuro \\
\hline & Asma' & Syawal \\
\hline & Pengisian & Muthih \\
\hline
\end{tabular}

Ustadz Sofwan as the badal ndalem explained that the raga mini is in accordance 
with the rules and the purpose of the salafi ulemas. Where mujahadah is its readings obligated by the religion of Islam. While the riyadlah is mentioned as a form of restraint of lust or in the Javanese language term it is called tirakatan, derived from the Arabic word taraka, meaning to restrain. So riyadlah contains nakirah, restraining from all the things forbidden by Allah. Riyadlah can be done in a variety of ways, such as melek mbengi (staying awake), learning and fasting. The book used in the teaching of the kanuragan is called al-Mujiz. The book written by KH Mahmudi contains asma', hizb, shalawat and has 232 pages that give details about the kanuragan science.

\section{THE MOTIVATION OF STUDENTS IN LEARNING THE KANURAGAN SCIENCE}

The students are expected to be really able to respond and anticipate all the problems of life that come to the surface as the impact of globalization or the demands of the times with full confidence, constancy and confidence which is always based on the wise and discerning nature, in which the students are expected to have a strong, consistent commitment and their existence can be accounted for, so in the end the students will become flexible, not aggressive and radical, as well as being able to support education in order to realize and preserve the struggle of the scholars and the legacy of the salafi ulemas.

The expected result is that the education system will maintain the salafi values (innocence). The real meaning of innocence here is not opposing changes or and modernization, but rather a symbol of honesty to prevent the negative effects of the globalization that may destroy the personality of the nation, and to keep the Islamic aqeedah strong from uprising that may affect the Islamic religious order and authority.

With regard to the long hair tradition which is the typical of this pesantren, it is not a symbol of negative behavior, but rather a characteristic that needs to be analyzed and examined in depth that at its core is a desire to have a vision into the future, like growing hair lengthwise that reflects perseverance in the "fight for the religion to the last blood". In fact the final message emphasized by pembaurekso is to become successful students they should be "AKIK" (active, creative, imaginative, and communicative) and be strong in "DUIT" (prayer, effort, faith and piety). Should the two principles be achieved and expressed in life, then it is not impossible that someone could reach the happiness of the world and the hereafter.

The students of Rohmatul Ummah have a different motivation in learning the science of kanuragan. This motivation can be divided into two major categories, namely worldly motivation and unworldly motivation. Due to the education 
students receive is far from a model of modernization, the tendency to think in an worldly manner is very high. Based on interviews with the students, the research results in the field can be categorized as follows:

\begin{tabular}{|l|l|}
\hline Worldly Motivation & Unworldly Motivation \\
\hline Protecting yourself from cults & Integrating syariah and hikmah \\
\hline Making jadhug & Practicing salafi teachings \\
\hline Learning martial arts & Seeking divine reward \\
\hline Learning traditional healing & Helping others \\
\hline Aiming for thuma'ninah way of life & Abstaining from immoral deeds \\
\hline
\end{tabular}

\section{VARIOUS BENEFITS OF LEARNING} THE KANURAGAN SCIENCE

Fasting is a means of restraining oneself from lust. The true results of the fast are to live peacefully, and to not easily lose temper. Only in the tranquility of life will one's prayers be heard by God. In that sense, the fast also includes efforts to restrain oneself from lust in everyday life and to practice good behavior in life.

The practice of the prayer song is highly recommended by mutih fasting for 40 days. Observing mutih fasting for 40 days and getting up early at dawn while reciting a prayer song with patience and gratitude become the basis of establishing the will and obtaining the power from God. Mutih fasting should be observed in one's spare time; it is when there is no hardship. In the words of the Hadith, utilizing the opportunity before the arrival of hardship. This is called tirakat in the term of Javanese Islam.

Viewed from its benefits, the kanuragan science taught the Rohmatul Ummah pesantren can be divided into three categories:

\begin{tabular}{|l|l|l|}
\hline Ibadah & Spiritual power & Healing \\
\hline Staying close to Allah & $\begin{array}{l}\text { Balancing bodily and } \\
\text { spiritual needs }\end{array}$ & $\begin{array}{l}\text { Helping members of the } \\
\text { community in the form } \\
\text { of spiritual healing }\end{array}$ \\
\hline $\begin{array}{l}\text { Practicing salafi } \\
\text { ulemas' teachings }\end{array}$ & $\begin{array}{l}\text { Promoting physical } \\
\text { self-confidence in de- } \\
\text { fending Islam }\end{array}$ & $\begin{array}{l}\text { Providing assistance } \\
\text { for those possessed by } \\
\text { spiritual beings }\end{array}$ \\
\hline Staying away from vice & $\begin{array}{l}\text { Ora tedhas wadhung } \\
\text { lan linggis }\end{array}$ & $\begin{array}{l}\text { Helping someone to be } \\
\text { patient when dealing } \\
\text { with illness }\end{array}$ \\
\hline
\end{tabular}




\begin{tabular}{|l|l|l|}
\hline $\begin{array}{l}\text { Observing tirakat and } \\
\text { taubat }\end{array}$ & $\begin{array}{l}\text { Becoming a guard in } \\
\text { war to uphold Islamic } \\
\text { teachings }\end{array}$ & $\begin{array}{l}\text { Giving assurance that } \\
\text { every illness has its own } \\
\text { cure }\end{array}$ \\
\hline
\end{tabular}

\section{KANURAGAN SCIENCE TEACHING MODEL}

The teaching of the kanuragan science at the Rohmatul Ummah pesantren is not simply a specially standardised subject but it has become a unique science that has always been the characteristic of the salafi Pesantren. The Kanuragan science teaching Model in this pesantren still qualifies as very traditional, where the kanuragan is taught with an ijazahan model. When students need specific science, they could immediately come to Kiai/badal as the Mujiz. After describing the type of science they need, the Mujiz will provide a set of practices that must be done. After the practices were given, the students are required to complete them.

KH. Mahmudi said that "ojo gampang batalke (ifthar) ijazah" (do not easily cancel the ijazah given by Kiai). It indicates a spiritual pledge between a student and Kiai that the science is to be completed. As for the model, it can be categorized into two teaching models:

\begin{tabular}{|l|l|}
\hline Individually & Collectively \\
\hline $\begin{array}{l}\text { Students come directly to ask for } \\
\text { the ijazah }\end{array}$ & Baiat missal \\
\hline $\begin{array}{l}\text { Kiai provides practices to the stu- } \\
\text { dents in person }\end{array}$ & $\begin{array}{l}\text { In a pengajian (Qur'anic recitation), the } \\
\text { Mujiz gives the students the ijazah }\end{array}$ \\
\hline & Tafa'ulan (transferring spiritual power) \\
\hline
\end{tabular}

The Books of wisdom used in the kanuragan include: Manbaul Hikmah, Syamsul Ma'arif, Khuzainatul Asrar, Ta'lifHikmah, Silahul Mu'min, Mujarrabat Kubra, Manaqib, Dalailul Khairat and so forth.

\section{CONCLUSION}

The science of kanuragan has become a unique tradition in Java. In fact, the kanuragan science is also taught at the pesantren. This paper presents several important issues which are the results of research conducted. First, the kanuragan science taught at the Rahmatul Ummah pesantren is a kind of kanuragan based on the science of wisdom - which contains asma', hizb, shalawat, traditional medicine and martial arts. Second, the motivation of the students learning the kanuragan at the Rahmatul Ummah pesantren is for taqarrub ila Allah. The other goal is to help others, both physical assistance or self-defense and medical aid. 
Third, the benefits of learning the kanuragan science at the Rahmatul Ummah pesantren are very diverse. At least there are two benefits; for the students and for others. The student can benefit from the science in the form of jadhug and self-confidence. Other benefits include making people comfortable and free from diseases. Fourth, the teaching of the kanuragan science at the Rahmatul Ummah pesantren can be done individually (from the Mujiz to the students directly according to the levels of science, and collectively (joint practices).

\section{BIBLIOGRAPHY}

Abdul Fattah Jalal. 1998. Min Ushu al-Tarbiyah fi al-Islam, terj. Hery Noer Ali Bandung: Diponegoro

Abdurrahman Saleh Abdullah. 2005. Pendidikan Berdasarkan Al-Qur'an. Jakarta: Rineka Cipta.

Achmad Chodjim. 2003. Mistik dan Makrifat Sunan Kalijaga. Jakarta: Serambi Ilmu Semesta.

Aulia. 2009. Ritual Puasa Orang Jawa. Yogyakarta: Narasi

Brian Morris. 2007. Antropologi Agama, cet.2. Yogyakarta: AK Group

Budiono Heru Satoto. 2009. Konsepsi Spiritual Leluhur Jawa. Yoyakarta: Ombak

Bustanudin Agus. 2007. Agama dalam Kehidupan Manusia. Jakarta: PT. Raja Garafindo Persada

Capt. R. P. Suyono. 2009. Mistisisme Tengger. Yogyakarta: LKiS

Endang Saifuddin Anshari. 1991. Ilmu, Filsafat dan Agama. Surabaya: Bina Ilmu

Haidar Putra Daulay. 2004. Pendidikan Islam dalam Sistem Pendidikan Nasional di Indonesia. Jakarta: Kencana.

Husni Rahim. 2001. Arah Baru Pendidikan Islam di Indonesia. Jakarta: Logos Wacana Ilmu.

Khoiron Rosyadi. 2004. Pendidikan Profetik. Yogyakarta: Pustaka Pelajar.

Marshal G.S Hodgson. 1999. The Venture of Islam: Iman dan Sejarah dalam Peradaban Dunia Masa Islam Klasik. Jakarta: Paramadina

Mochtar Buchori. 1994. Spektrum Problematika Pendidikan Islam di Indonesia. Yogyakarta: Tiara Wacana Yogya

Muhammad Fadlil al-Jamili. 1966. Al-Falsafah al-Tarbawiyyah fi al-Qur'an. Dar Kitab: Al-Jadid

Muhammad Sa'id Ramadan. 1998. Finding Islam Dialog Tradisionalisme-Liberalisme Islam. Jakarta: Erlangga

Muhtarom HM. 2005. Reproduksi Ulama di Era Globalisasi Resistansi Tra- 
disional Islam. Yogyakarta: Pustaka Pelajar

Olaf Schumann. 2001. Pemikiran Keagamaan dalam Tantangan. Jakarta: Gramedia Widiasarana

Parsudi Suparlan. 2001. The Javanese in Suriname: Ethnicity an Ethnically Plural Society. New York: Program for South Asian Studies ASU

Sindu Galba. 1991. Pesantren Sebagai Wadah Komunikasi. Jakarta: Rineka Cipta

Syed Sujjad Husain \& Syed Ali Ashaf. 1398. Crisis in MuslimEducation. Jeddah: Hodder and Stoughton.

Tjaroko Hp Teguh Pranoto. 2007. Spiritualitas Kejawen. Yogyakarta: Kuntul Press

Toha Jahja Omar. 1971. Ilmu Dakwah. Jakarta: Pertjetakan Negara

Widada dkk. 2008. Kamus Bahasa Jawa (Bausastra Jawa). Yogyakarta: Penerbit Kanisius

Yasmadi. 2002. Modernisasi Pesantren Kritik Nurcholish Madjid Terhadap Pendidikan Islam Tradisional. Jakarta: Ciputat Press 
